\title{
Honoring Student "Voice" in Investigating Student Identity Development in a Narrative Study: A Methodological and Analytical Example
}

\author{
Deborah Lees
}

Torrens University, Australia

\author{
André Van Zyl \\ University of Johannesburg, South Africa
}

DOI: https://doi.org/10.18778/1733-8077.18.1.02

\section{Keywords:}

First-Year Experience;

Student Identity

Construction;

Narrative Inquiry;

Narrative Methods;

Student Voice

\begin{abstract}
Multiple, interrelated narrative methods were employed in a doctoral study purposed to investigate the student identity development of seven first-year participants. This approach provided them with multiple opportunities to convey their unique first-year experiences and revealed rich understandings of how they constructed their identities at a private higher education provider in Johannesburg, South Africa. The purpose of this article is to demonstrate that fostering the trust of participants ensured the formation of rich biographical narrative portraits through multiple narrative-type collection methods and forms of analyses, resulting in rich tapestries of personal experience, which were constitutive of their identity formation. Each participant's narratives revealed their particularities, complexities, and unique experiences of their first year. Although each participant experienced their first year of study very differently, this article weaves in the firstyear experiences of one person into its fabric. The narrations of Kondwani (pseudonym), a Zambian student, are used to illustrate how her voice emerged and was held in a trustful research relationship. Her case is representative of all the participants in that it is an exemplar to illustrate the richness of the individual narratives gleaned from carefully chosen methods and forms of analysis that were employed in the study.
\end{abstract}

Deborah Lees, Ph.D., is an Adjunct Senior Lecturer at Torrens University, Australia, and resides in Johannesburg, South Africa. She holds a Master's degree in Adult and Community Education. Her extensive years in higher education leadership roles have developed her research interests in the first-year student experience, student transition, student identity, and narrative-based studies. email address: deborah.lees@adj.torrens.edu.au

André Van Zyl has a Master's degree in Strategic Management and a Ph.D. in Higher Education. His main research focus is in the area of student success with a specific focus on first-year students. André was responsible for initiating the First-Year Experience (FYE) initiative at the University of Johannesburg (UJ) and spearheaded the setting up of a National Resource Center for the FYE in South Africa. The South African National Resource Center (SANRC) is now fully functional at the UJ. He has been working at UJ since 2004 and has worked as a Learning Development facilitator, FYE coordinator, and since late 2012 as the Director of the Academic Development Center at the University of Johannesburg. email address: andrevz@uj.ac.za 


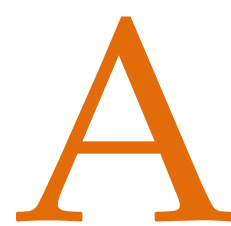

uthors from various backgrounds (see: Bruner 1986; Polkinghorne 1988; Clandinin and Connelly 2000) have suggested that telling stories is a means of making sense of experiences. Narrative Inquiry, according to Clandinin and Connelly (2000:32), is a way of truly understanding human experience:

It is a collaboration between researcher and respondents, over time, in a place or series of places, and in social interaction with milieus. An inquirer enters this matrix in the midst and progresses in this same spirit, concluding the inquiry still in the midst of living and telling, reliving and retelling, the stories of experience that make up people's lives, both individual and social. Simply stated...narrative inquiry is stories lived and told.

Since the student protests in South Africa started in 2015, much research has focused on issues of social justice for students in South Africa. The 2015 "\#Rhodesmustfall" and the "\#Feesmustfall" student protests called mostly for the decolonization of campuses and the curriculum in South African universities and illustrated disdain for the high tuition fees that students were paying (Boughey and McKenna 2016:1). In their article, which discussed these student protests, Boughey and McKenna (2016:7) called for more reflective and theoretical work to be done so as not to perpetuate the current "common-sense" assumptions made about students in the field of academic development. On the back of the protests has followed "a powerful mobilization around the lived experiences of students" (Ngabaza, Shefer, and Clowes 2018:1).

This has further supported the growth in the use of narrative as a tool to better understand the experiences of higher education students in South African higher education research (Boughey and McKenna 2016; Chinyamurundi 2016a; 2016b; 2018; Pather and Chetty 2016; Carolissen and Kiguwa 2018; Ngabaza et al. 2018).

Factors contributing to the growth of narrative studies in South Africa include an awareness of how narrative accounts can assist in recollecting and experiencing the past through a focused lens (Coetzee and Rau 2017). Narratives, therefore, provide the capability to answer questions about student transition and, in turn, how students live and convey their identities.

\section{Defining and Positioning Identity}

In this article, identity is viewed as "a set of reifying, significant, endorsable stories about a person. These stories, even if individually told, are products of a collective storytelling" (Sfard and Prusak 2005:14). This definition implies that the collections of stories that commencing students in higher education tell and reflect are representative of their identities. Sfard and Prusak (2005) further clarify that although the term "identity" previously emanated from mostly psychological discourses, it now inhabits research spaces in many social and humanistic sciences. The developing identity of being a student is not investigated as a psychological concept in this article, it is rather seen as a simultaneously cultural, historical, social, and personal construction. The argument that self-narratives are expressive of and constitutive of identity is well documented in the literature (Hardy 1968; Bruner 1986; Giddens 1991; Ricouer 1991; McLellan 1994; Hitchcock and Hughes 1995; McAdams 1996; Polkinghorne 1988, Clandinin and Connelly 2000; Czarniawska 2004; Singer 2004; Sfard and Prusak 2005; Yuval-Davis 2006; Riessman 2008; Gill and Goodson 2011; McAdams and McLean 2013). 
Polkinghorne (1988:150) provided a brief yet very succinct argument as to why a narrative study is relevant when addressing how identities are revealed and developed:

The tools being used by the human disciplines to gain access to the self-concept are, in general, the traditional research implements designed for formal science to locate and measure objects and things... we achieve our personal identities and self-concept through the use of the narrative configuration, and make our existence into a whole by understanding it as an expression of a single unfolding and developing story. We are in the middle of our stories and cannot be sure how they will end; we are constantly having to revise the plot as new events are added to our lives. Self, then, is not a static thing or substance, but a configuring of personal events into a historical unity which includes not only what one has been but also anticipations of what one will be.

\section{A Methodology to Build Trust and Honor Student Voice}

Multiple, interrelated methods to better understand the experiences of participants (Denzin and Lincoln 2013) were employed. The careful choice of various narrative methods to gather field texts, knowledge about the everyday lives and worlds of the participants, as told by them, ensured trusting reciprocal relationships between them and the researcher. Further, they facilitated keeping the stories of participants intact and authentic. Participants felt that they had a contribution to make and appreciated the fact that they were given "voices of authority" and the freedom to share what they were comfortable with regarding their first-year experiences (Clandinin and Connelly 2000).
The methods employed and described comprehensively in the next section were chosen specifically to honor the voices of the participants. Narrative interviews were held four months into their first year of higher education study. The remainder of the field texts were gathered at the end of their first year to determine how they had navigated their first year, in retrospect. Table 1 provides a summary of each form of field text set collection method with a summarized statement illustrating how their voices were intentionally sought and honored throughout the research.

\section{Table 1 Methods employed to honor participants voices}

\begin{tabular}{|c|c|}
\hline $\begin{array}{l}\text { Field text collection } \\
\text { method }\end{array}$ & $\begin{array}{l}\text { Description of how } \\
\text { participant voices were } \\
\text { sought }\end{array}$ \\
\hline Narrative interviews & $\begin{array}{l}\text { Moved away from } \\
\text { categorical-form responses } \\
\text { towards natural, open- } \\
\text { ended conversation } \\
\text { (Mishler 1986) }\end{array}$ \\
\hline $\begin{array}{l}\text { Images-participants } \\
\text { generated photo-elicitation }\end{array}$ & $\begin{array}{l}\text { Allowing participants to } \\
\text { bring an image of their } \\
\text { choosing gave them power } \\
\text { and control in the research } \\
\text { process }\end{array}$ \\
\hline $\begin{array}{l}\text { Drawing "Rivers of } \\
\text { Life" and participant } \\
\text { conversations whilst } \\
\text { drawing }\end{array}$ & $\begin{array}{l}\text { The analysis was } \\
\text { conducted based on the } \\
\text { explanations provided } \\
\text { by participants, not the } \\
\text { drawings themselves }\end{array}$ \\
\hline $\begin{array}{l}\text { Focus group sharing and } \\
\text { reflecting on first-year } \\
\text { journeys }\end{array}$ & $\begin{array}{l}\text { Participants were given } \\
\text { the freedom to share what } \\
\text { they felt comfortable with } \\
\text { the group }\end{array}$ \\
\hline
\end{tabular}

Source: Self-elaboration. 
Through sharing her experiences of commencing higher education with participants, and what she was aiming for in the study, the participants became more responsive to the researcher. Their level of comfort as participants in the research was heightened, and a relaxed rapport was developed. Sharing stories diminished the distance between the researcher and participants, created trust, and positioned the researcher in the role of "insider"' (Berger 2015).

The participants' full stories were shared in the biographical narrative portraits rather than fragmenting their lived experiences of the first year into codeable categories to control their meanings (Riessman 2002:2). Kim (2016) explains that biographical narrative inquiry tells personal stories about others and respects and values what they say. With the tapestry of field text sets gathered from the participants, seven rich, layered, deep participant biographical narrative portraits were crafted to determine how they had woven or constructed their stories by recreating one composite story of each of their experiences. Cohen, Manion, and Morrison (2011) affirm that telling others' stories in such a way knits text and content, stays true to individuals by ensuring their dignity, it sanctions cause and consequence, and allows events to unfold naturally.

All participants signed consent forms for their field texts, and subsequent narratives to be used for various purposes, provided that their anonymity was ensured. Final crafted biographical narrative portraits were shared with each of them to gain their approval or allow them to edit their stories before the doctoral study was finalized. Examples of the feedback received from them were positive and required no changes or small amendments. As an example, Kondwani wrote, "whilst I was reading it, it made me look back at how I've grown from the first year until now. I'm glad to have gone through that journey."

The anticipated use of their texts for publication purposes to improve the student experience at the research site was explained. Chase (2011:424) explained that narrative researchers often include longer participant narratives in their publications, which may make participants feel vulnerable and exposed. She advised that the researcher should inform them again and ask permission to use such extended narratives. Kondwani's permission to include her narratives was sought and given approval once again before submitting this article for publication.

The study employed the use of a qualitative research paradigm and a complementary methods research design-type to answer two research questions: "What are the first-year experience stories narrated by students in South African higher education?" and "What are the common identity themes of firstyear students based on their narratives of first-year higher education experience?"

The term "field text" rather than "data" was used as the appropriate term for the narrative inquiry. The interpretive nature of field texts allowed the researcher to re-narrate stories told by the participants.

Although individual narrative stories already guarantee variety in results, representivity and perspective across participants were necessary to increase a variety of perspectives and stories and to enrich the study results (Cohen, Manion, and Morrison 2011:103). Purposeful sampling was used to intentionally select the participants so that the central 
phenomenon could be better understood (Cresswell 2002:194). Josselson, Lieblich, and McAdams (2003) posited that saturation never occurs when telling personal stories, as each participant has something unique to add to the study. However, seven participants were sufficient to gain multiple, unique, rich understandings of first-year experiences.

Including Kondwani, the participants comprised four South African students and three international students from Liberia, Zambia, and one other sub-Saharan country, respectively. One participant was reluctant to reveal the identity of her home country due to its political situation.

Kondwani's case is representative of all the participants in that it is an exemplar to illustrate the richness of the individual narratives gleaned from carefully chosen methods that were employed in the study. However, there were commonalities across the seven participants' experiences, which are briefly discussed later in the article. Each of the seven participants' narratives revealed their particularities, complexities, and unique experiences. No two research participants had the same experiences or even experienced the same events in the same ways. Each participant was a multicultural subject (Denzin and Lincoln 2013:27), resulting in each one of them experiencing their first year of study very differently.

The next section provides a brief overview of one of the seven participants in the study-Kondwani. It is important to illustrate her narratives as they are a descriptive and formative exemplar of the process of her student identity construction, which was simultaneously strong and delicate. Her identity was strong as identity is strongly held onto during times of major tensions or transitions (Gid- dens 1991). It was also delicate because the stories that she expressed were only some of the many other stories that could be told of her first-year experience (Giddens 1991). Her narratives, as with the other participants, provided a snapshot in that the stories were accepted for what they were at the time and used as a lens for an investigation into her identity development at the time of the study. Her introduction is shared as each of the field text collection methods explained after that provides examples of her narrative contributions that were used to create her final narrative portrait.

\section{An Introduction to Kondwani}

Kondwani was a Zambian student. She had commenced her studies in the field of Information Technology.

Despite having a frantic start to her studies, Kondwani got through her first year of study through her faith in God, and her friendly, quiet confidence, and determination. This allowed her to make friends and take charge of situations. She was tested by academic pressures and loneliness, and she missed her family. She carried many worries on her shoulders and felt the need to always take responsibility for everything she did and to do even better. She was the first-born child in her family, which placed a lot of pressure on her as she wanted her family to be proud of her. She was an individual who was hard on herself, never letting her guard down. With a strong sense of duty towards her family and herself as a student, her first-year story is one of enduring and overcoming the obstacles she faced. She was confident enough to evaluate her new campus and made suggestions for improvement based on her experiences. Her story was one of personal transformation through perse- 
vering through personal and academic challenges over her first year of study.

The following section summarizes the carefully chosen methods employed with each of the seven participants to honor their "voices," using Kondwani's narrations as an exemplar.

\section{Methods Employed for Field Text Set Collection}

\section{Narrative Interviews}

The aim of conducting narrative interviews was to glean detailed accounts instead of short answers and general statements from participants (Riessman 2008:23). Categorical forms of response were avoided and moved towards narratives of natural, open-ended conversation (Mishler 1986).

The transcripts were rewritten into a draft narrative sketch showing the main threads of the conversation and then finalized (Gill 2005).

Selected examples illustrate Kondwani's initial experiences in her first four months of becoming a first-year student.

Arriving at the institution to study, she was informed that she "should have" arranged her study visa in Zambia before coming to South Africa. She was only given one week by the institution to arrange her study visa, police permit, and to gain health clearance in Zambia, which was extremely stressful for her:

There was so much involved, and there was so much up and down movement, and the expenses. I had come to South Africa, I had to fly back to Zambia and then do all those things. It required money. It was so intense...I almost lost hope.

In this process, she missed the full week of orientation prior to the formal start of the semester and almost the whole first week of classes. She had missed a lot of vital information:

...when I came back, I found out that I was a week late, and I was slacking a bit, especially in the different subjects...the lecturers had already covered the introductory week, it was hard for me.

At the outset of her studies, she experienced extreme homesickness:

I thought that maybe this wasn't the place for me...I missed being with my family and friends. I almost broke down at a certain point. I was in my room, thinking about everything, and I just became so emotional. I felt like I was enclosed in a box-I really needed someone to talk to. I had no one to talk to...

Kondwani was the eldest child in the family and felt the need to be a good example to her siblings and make her parents proud of her:

My parents bringing me here is... it's a lot, and I just put that into consideration and know at the end of the day, I'm not only doing this for myself but for my family back home. Being the firstborn brings many challenges with it. At the end of the day, you're going to make your parents proud. So, I put that into consideration.

She described her difficulty in seeking support for her academic work that she was struggling with:

I was too shy to ask someone because maybe I would be embarrassed...but I'm learning to reach out for 
help. I went to find a tutor who has really helped me, it's helped me in my grades as well... I am doing better now than previously, with his help. I am doing my best not to be reluctant, but rather to push and give it my all.

Getting to know her residence peers was a disconcerting challenge for her:

Everyone is in their own world. You can't go and knock on someone's door and talk to them because everyone seems to close you out.

She summed up her first few months of being a higher education student as:

...an up and down experience from the time I enrolled to actually getting here. Finding friends was difficult, just getting to know the place. When I arrived on campus for the first time, it was my first day of ever being in South Africa. I've never been here. So being in a new place, a new environment, was kind of difficult...integrating with people...

However, she did not give up in her first few months:

...eventually, with trying, I got used to everything. It was very difficult, the technology and everything, everything was so new to me, and the whole experience itself. With time, I ended up making friends. The subjects that we do here were a challenge as well, but, with time, I got used to it.

In the examination of the narrative interview conducted with Kondwani, empirical evidence of how stories are shaped for their contextual, situated telling was found. This is evidence that narrative form is molded by the social context in which the individual is immersed, and that narrativity as a discursive mode is central to the social and institutional world of the individual (Thornborrow and Coates 2005:7).

\section{Images-Participant Generated Photo-Elicitation}

Adding and mixing methods of collecting field texts offered the potential to enhance the capacity for a social explanation by the participants.

The visual and the sensory are also worthy of investigation but cannot always be communicated easily by verbal means (Eisner 2008). Pushing beyond the non-linguistic dimensions in research and expanding the investigation by using visual and arts-based methods was ensured as these offer other expressive possibilities that allow access to different levels of experience (Bagnoli 2009:547-548). The creative activity of using visual methods and methodologies is the starting block for emergent thoughts about personal experience and identity, which are conveyed to the researcher (Gauntlett and Holzwarth 2006:82). By creatively mixing methods, "out-of-thebox" thinking came to the fore, which allowed new ways of cross-examining and understanding social experiences and lived realities (Mason 2006:9-10).

Through reviewing relevant literature, the emergence of graphic elicitation as a rich instrument to uncover experiences that are not otherwise understood became clear (Crilly, Clarkson, and Blackwell 2006; Bagnoli 2009; Copeland and Agosto 2012; Rodriguez and Kerrigan 2016). Photographs have, for example, been used as a way of evoking memories of an experience (Rose 2012:307). In this study, bringing their images assisted participants in reflecting on their first year of higher education. In addition, they assisted in investigating the daily taken-for-granted thoughts, experiences, and routines of the participant (Rose 2012:306). Guillemin 
and Drew (2010:177) explain that participant-generated photo-elicitation opens the intricacies of the phenomenon being investigated.

In the review of literature, participant-generated photography most often involves participants being given a camera and being tasked with taking pictures of their experiences or things that are important to them in a particular context (Guillemin and Drew 2010:176). However, in this study, each of the participants was asked to bring an already-taken image to a group session, which they felt best captured their experience of their first year at the higher education institution. The images brought by participants could take the form of a photograph, a meme, a photograph downloaded from the Internet, or a picture from a magazine. This differs substantially from the traditional method of eliciting participant-generated photography but allowed participants to select the image themselves, thus giving them power and control to bring an image with which they were comfortable. In addition, this method resonated with participants who, between the ages of 18 and 20, were avid consumers of social media on mobile phones. They could access an image reminding them of their first-year experience easily. It allowed them to use it as a vehicle and a metaphor to explain it in terms of why it reminded them of their first-year experience. It also fitted well with the field text collection plan of using visual texts for an opening activity as a field text set collection point.

Participants were asked to bring an image that in retrospect reflected something important or poignant from their experiences from their first year. Selecting an image with this in mind ensured that each participant had utilized time and effort in advance to do some reflection of their first year in higher education and, as a result, they arrived on the day with some thoughts and positionings of self regarding their experiences already.

The opening activity allowed students to start performing their identities in the discussion of their images. The descriptions given by participants are termed by Croghan, Griffin, Hunter, and Phoenix (2008:347) as "forms of self-accounting" in that identity work is performed that focuses particularly on the image.

Participants' verbal input as to why they chose their image as a primary field text set was used. No visual analysis of the photographs took place. Only their talk about the selected image(s) was transcribed into a field text set.

Kondwani's image that reminded her of her first year depicted her sitting in an airplane as she embarked on her initial journey from Zambia to study in South Africa. She was both nervous and excited at the same time:

That was me on my way to South Africa from Zambia, the picture represents me being nervous but lowkey excited about going into my first year...

She explained that she was sad to leave her family behind but excited at the prospect of the new life journey ahead of her-she knew that it would be a challenging road ahead.

Despite the simplicity of the image that she provided, a self-taken photo of her on her plane trip from Zambia to South Africa portrayed the most poignant or significant experience of Kondwani's first year-leaving her home and her country to start her higher education studies in South Africa. 


\section{Drawing "Rivers of Life" and Participant Conversations while Drawing}

Lived experience also takes place in visual and sensory dimensions, which merit investigation but cannot always be articulated in the form of language (Eisner 2008). Leitch (2008) noted the growing interest in the combined use of narrative and drawing to understand the world of those being researched. The work of Guillemin and Drew (2010) unveiled the growth of literature in research (Evans and Hall 1999; Mirzoeff 1999; Emmison and Smith 2000; Banks 2001; Sturken and Cartwright 2001; Van Leeuwen and Jewitt 2001; Rose 2007), which is dedicated to the analysis and interpretation of visual images.

Participants were asked to draw "Rivers of Life." The "River of Life" concept was introduced as a metaphor for the journeys of their first-year experience. Using "Rivers of Life" has been utilized in research as a participatory visual narrative method that facilitates the visual telling of stories of the past, present, and future (Moussa 1994; Fisher and White 2001; Fullana, Pallisera, and Montserrat 2014). Participants used the metaphor of a river to reflect on their first-year experiences, encompassing both the positive aspects and the challenges along the way. They were asked to draw a river to represent their first-year journey at the institution, including significant elements that had contributed to shaping their experience.

Conversations between participants whilst drawing their pictures were audio-taped. The drawings themselves, the explanations of their drawings given by the participants, and the informal banter taking place between participants during the drawing process were transcribed as field texts.
Although there are various approaches according to which visual texts can be analyzed and interpreted (Guillemin 2004; Rose 2001; 2007; 2012), participants' interpretations and explanations were integrated verbatim into the portraits-“you shouldn't try to analyze each creative artifact because that is better done by the person who made it" (Gauntlett and Holzwarth 2006:87).

Giving the participants space to create their drawings of experience enhanced the trustworthiness of this study as the participants had the power to create and contribute to the study providing transactional validity (Schulze 2017). The participants' drawings gave them a voice, positioning them as expert authorities on their lives (Schulze 2017).

Recording participant conversations whilst drawing proved to be a rich field text. The students were relaxed and engaged in natural conversation during which they opened up to each other. The transcriptions revealed thoughts, events, and emotions which had not been gleaned from any of the other field texts.

Kondwani revealed her strong religious faith in conversation with other participants whilst drawing "Rivers of Life":

....aren't you like?...“Okay, God, maybe you are trying to show me a sign like...okay, that wasn't for me?" I kept on trying, but He kept closing the door instead. Your plans are not God's plans.

\section{Focus Group Sharing and Reflecting on Participants' First-Year Journeys}

Once the drawings had been completed, participants were allowed to present their "River of Life" 
first-year experience story to the focus group. Each participant fixed their A3-sized drawing to a wall and explained their first-year story referring to their drawing while sharing their story. Other participants were invited to ask questions and seek clarity when and if necessary. These presentations were audio-recorded and transcribed for analysis. The focus group format increased the opportunity for participants to uncover new and possibly unexpected learning (McDrury and Alteiro 2003:34). The participants listened to each other, illustrated, and shared multiple realities of their first-year experiences in the discussion. The researcher relied on the meaning-making that participants attributed to what they had drawn.

Kondwani pointed out various literal aspects of her drawing, saying things like:

We have the sun, the clouds, there's a tree, the river, there's a quote, and there's me.

She indicated that the sun depicted her positive moments, and the clouds depicted the moments that had been hard for her. At the same time, the green leaves depicted her positive experiences, and the yellow leaves were her more negative experiences during her first year. Despite hardships, she had managed to move forward and overcome them. She mentioned that she had been scraped by the brown rocks in her river as her journey had not been easy:

It's been very overwhelming...

She only made mention of different experiences but did not seem to want to divulge too much detail to the group. She shared that she had endured a challenging first year and so included writing in a quote on her drawing that read:
"A journey of a thousand miles begins with one step."

She qualified this by saying that she had not given up even though her year had not been easy-she had experienced difficulties of her own. She attributed her faith in God for getting her through her first year:

He's seen me through my journey.

\section{Participants' Personal Reflections on Sharing Their Experiences}

While seated together after presenting the individual stories of their first-year experience, participants were asked if they had learned from the experiences of the other participants over the period of their involvement in the research. These interactions were audio-taped and transcribed. In addition, the following question was asked: "What was the value for you in being part of this study?" They were asked to submit this in an email as a reflective piece of writing. These reflective pieces of writing were integrated into the final biographical narrative portraits.

Kondwani's verbal reflection on whether she had learned from the narrated experiences of the other participants is provided verbatim below, honoring her "voice":

I really didn't know what to expect, and I was a bit nervous about how things were going to turn out. I wondered if I would be comfortable with the other respondents because I did not know any of them. I was scared about how I was going to stand up and speak to them. Surprisingly, I've been comfortable expressing myself. Listening to everyone's different experiences has been a good thing. Despite the different challenges that we've all faced-yes, they broke 
us down-but we all have that positivity in us-the fighting spirit that things will get better. We all fall, lying in different places, but we're still getting back up to try to see the good in it. So, it's good to see that through these different challenges, that we are all growing in different aspects of our lives.

Kondwani's written reflection is presented below and was incorporated into the final narrative portrait:

My experience of the first year through being a participant in the research was so overwhelming. From the last time I was interviewed until our last encounter with you, I have been through so many changes as an individual. By this, I mean that I've grown through the different challenges or experiences I have faced. From the activity we had on that day, telling our stories through a drawing was a first-time experience as I had never done it before. In the beginning, I did not know how to go about it, but eventually, I got the hang of it and found it easy to tell my story through a drawing.

Being able to share my story through the drawing with others was nice because it helped me to open up and share the experiences that I had during my first year. On the other hand, hearing other people's stories through their drawings was great because it made me realize that we all go through similar experiences at the end of the day.

There's so much value in sharing stories of our experiences in the first year. It helps us relate to one another, in the sense that you as an individual are not the only one going through that problem or situation-even if you feel that you are alone-others are going through the same things. When we share our experiences with others, it helps us to know that we can all get through it and try to help each other. A problem shared is a problem solved.
What I really learned from the others, is that despite the different encounters we faced, we all grew and continued pushing ourselves through. We all tried to be positive about things at the end of the day. We all had a mindset of putting academic work as our main priority but also remembered that we have a social life. Our social lives allowed us to meet people that help us or teach us different lessons. Through this we continue to discover who we are, knowing that we are growing and learning through the different experiences we face in every aspect of our lives.

These personally narrated, fragmentary perspectives on Kondwani's becoming experiences, illustrated that identity is socially constructed and constantly re-created in storied interactions by people and between people. Her identity development resulted from situated interactions during her first year where she picked up institutional, intrapersonal, and interpersonal cues for learning her student identity. The myriad, complex paths that she traversed, which were captured in her various field text sets, allowed a "bird's eye view" into her experiences.

\section{Narrative and Thematic Analysis}

Narrative analysis resides within the narrative inquiry in that it "understands lives as unfolding temporally, as particular events within a particular individual's life. The final result is a story. Instead of applying a stimulus/response approach, the researcher rather opts for opportunities where respondents can develop narrative accounts" (Riessman 2008:23). Narrative analysis was used in the first phase of the analysis to write up the biographical narrative portraits of the seven participants.

The analysis of narratives can be likened more to general qualitative research, where narratives are 
analyzed into themes and categories. Analysis of narratives was used in the second phase of the analysis where common themes were discovered across the participants' narratives by using Braun and Clarke's (2006) thematic analysis.

\section{A Trajectory for Analysis and Writing Up the Biographical Narrative Portraits}

The work of Kim (2016) offered a process for integrating and analyzing the fieldsets in that she encourages narrative researchers to "flirt" with texts. She defines flirting with texts (Kim 2016:188) as follows:

Flirting with data is an attempt to analyze and interpret the research data to exploit the idea of surprise and curiosity, as we don't know what is going to evolve and emerge until we deal with the data; it creates a space for us where we can discover ways to reach and negotiate our research aims with data; it encourages us to make time to embrace less familiar possibilities; and it is a way for cultivating ideas for finding yet another story, one we have not necessarily bargained for.

As James (2017) and Hunter (2010), Kim (2016) does not provide a "one-size-fits-all-method" for analyzing narrative field text sets as prescribing a specific method would result in researchers trying to fit their field text analysis into a given method.

Labov's model of analysis (Labov and Waletzky 1967), adapted by Mishler (1995), was used to craft the biographical narrative portraits. Labov's model is a trusted method used for narrative analysis (Mishler 1986; 1995; McCormack 2004; Riessman 2008; Patterson 2013). Mishler (1995) adapted Labov and Waletzky's model of 1967, explaining that a personal narrative comprises six components, which are explained below. Labov's work on narrative pro- vides legitimacy and methodological rigor in the qualitative analysis of human identities and personal experience (Johnstone 2016:543). However, Kim's (2016) notion of "flirting with data" was retained.

The term "portraits" was apt for the study-in employing a visual metaphor, the revealing of narrative portraits of each participant reveals a self-portrait in that each of their stories is told (Schiffrin 1996). "Just as an artist may display a portrait through composition and color, a story may display through a teller, telling experience" (Schiffrin 1996:199).

Research portraits were found to be useful as tools for maintaining the presence of the participants within the analytical process. The use of portraiture prevails mostly within the social sciences and specifically within the sociological study of education (Golsteijn and Wright 2013:300). In adopting narrative portraits to present the narrative findings, the researcher ensured that she focused on the personal and social context of participants through the insights that they offered (Golsteijn and Wright 2013:308).

Each narrative portrait was composed by following the steps below:

1. After the field texts were collected and transcribed (where appropriate), they were read and re-read to become familiar with what participants had storied.

2. Working through the text sets of each participant to create the ordering framework, the positive and negative influences on the identity of each participant were highlighted. The result was an integrated narrative portrait summary sketch for each participant. 
3. Each field text set was analyzed. The meaning that participants made regarding all their text sets collected was relied on.

4. Mishler's six components, which make up a personal narrative, were utilized. The six components were collapsed into three. This was because in the ordering framework it had become apparent that there were layers of meaning across different text sets on the same topics of conversation. Trying to fit participant narratives under six different headings for the stories became mechanical and broke down the authenticity of individual accounts of experience. The three main headings for each narrative portrait were re-designed as follows.

\section{Abstract and Orientation}

In each narrative portrait, a short overview of each participant's story was provided, along with context to provide the reader with a fuller context of who the participant was. Participants often first spoke of their time at high school as an introduction to their stories and how they came to study at the institution. In this article, Kondwani's abstract and orientation was shared verbatim in this article in her introductory paragraph named "An Introduction to Kondwani."

\section{Complicating Actions and Evaluation}

Complicating actions and evaluations were combined. The layers of field text sets, crafted together into participant stories of first-year experiences, provided rich information regarding events, sequences, and plots, with crises and turning points. The researcher stayed true to the stories told by the participants in the narrative portraits-their stories were presented as they told them.

\section{Resolution and Coda}

Participants' reflections were captured in each narrative portrait. They narrated their thoughts and expressed their perspectives about what they had gained from being a part of the study. This section also provided the opportunity to connect their first-year journeys with the present by explaining where they were in their academic careers at the time of writing up the research. The information under this heading was mostly gleaned from the focus group discussion, their verbal and written reflections on the value they gained from being participants in the study.

Each narrative portrait was presented chronologically/temporally as far as possible based on Mishler's (1995) typology for the analysis of narratives.

Each narrative portrait was given a title. The title ascribed to each participant's story was inspired by a significant event, tension, challenge, or strength that was narrated in a participant's story of the firstyear experience. Kondwani's story title was "A Journey of a Thousand Miles Begins with One Step."

With the tapestry of field text sets gathered for each of them, seven rich, layered, deep participant narrative portraits were created, to determine how they had woven or constructed their stories by recreating one composite story of each of their experiences.

\section{Pointers Crafted to Write Up the Narrative Portraits}

Respected authors in the field of narrative inquiry were investigated to draw up pointers to write participant narratives and transform them into public documents, which would be accepted in the scientific community (Bolivar 2002:16). In the absence of 
a fixed set of guidelines for writing up biographical narrative portraits of experience, the narrative research work of various authors (Bruner 1987; Bolivar 2002; Riessman 2008; Somekh and Lewin 2011; Maitlis 2012; Golsteijn and Wright 2013; Kim 2016) were drawn on to write them. It may be said that there can never be one set of guidelines for writing up a narrative portrait as such a thing is an art, and the artist (author) participates creatively in the process. However, the following pointers offered clear direction and structure.

\section{Read and Re-Read Each Narrative Portrait}

Reading and re-reading the narrative portrait several times as ideas can initiate different interpretations or new ideas for the portrait (Golsteijn and Wright 2013:310). In practice, each narrative portrait was re-crafted three to four times, often changing the ordering of events, sequences, and participants' thoughts to ensure that their stories were authentic and chronologically correct.

\section{Detail the Setting, as well as Researcher Feelings of Setting and Each Participant}

The narrative should detail the setting where the interactions took place. It should feature the researcher's feelings about the setting and the individual participant (Golsteijn and Wright 2013:308). Participants and the researcher's backgrounds and lives before coming to the institution were provided as a backdrop to their narratives of the first-year experience.

\section{Tell a Story That Is Interesting, Understandable, and Convincing}

A narrative must answer the question "Why?" "Why is this worth telling, what is interesting about it?" (Bruner 1987:29). A narrative must be about a sequence of events over time, which is structured comprehensibly. The narrative must tell something interesting-something that makes it exceptional in that it produces something that we did not expect (Bruner 1987:29). Good narrative research is not just one that gathers the different voices in the field or interprets them but one that makes the story understandable and believable. The unique biography must be written within a framework of general structure in a context that explains it (Bolivar 2002:16). The narrative should be carefully and authentically orchestrated to produce feelings of empathy and authenticity on the part of the reader (Kim 2016:197). The unique aspects of each participant's first-year journey and staying "true" to their stories as they told them were ensured. Each narrative portrait was inspired by using a distinguishing feature, event, or theme, which underpinned their story, to draw the reader into wanting to read each participant's story.

\section{Integrate the Field Text Sets into a Coherent Whole Using a Chronological Sequence}

The final narrative portrait does not violate or remove the voices of the subjects investigated as it does not apply categorical analyses of participants' words-"the nuances of the narrativization of a life can never be caught in a thematic category" (Bolivar 2002:13). In other words, do not interrogate the actual words uttered by participants to formal rules that force researchers to explain why participants say what they say (Bolivar 2002:16). Rather, the process of crafting a "true" narrative is to integrate field text sets into a coherent whole. The result is an understanding of the past events in retrospect, using a chronological sequence from beginning to end-if this is done successfully, a specific plot will emerge (Bolivar 2002:16). What was presented in each nar- 
rative were honest and authentic accounts of what each participant narrated. Participants' stories were not changed in any way and strove to integrate the set of field texts of each of them into a coherent whole to allow specific plots to emerge.

\section{“Clean Up" Speech to Make the Narrative Portrait Easier to Read}

Erase disfluencies, break-offs, and repeated phrases that serve no purpose to participant stories. Do the same for researcher speech where necessary (Riessman 2008:57-58). The researchers' utterances were removed from each narrative portrait. Without changing or manipulating what each participant told, disfluencies, break-offs, and repeated phrases were removed. Where participants uttered swear words, a letter or letters were removed and replaced with an asterisk.

\section{Focus on Preserving the Words Used by Participants However Long or Short Their Narratives May Be}

Quote the actual words of the participants extensively. Large, verbatim fragments should be placed into the narrative portraits (Golsteijn and Wright 2013:308). Glean and craft told stories and not "how" they told their stories. Preserve historical sequence and the wealth of detail contained in the long sequences of participants, rejecting the idea of generic explanations (Riessman 2008:74). Narratives can vary in length. A narrative may only be a few lines long in total but may vary to long and complex stories that comprise parts, or the whole, of the story of a person's life (Maitlis 2012:493). Do not fracture participants' accounts. Work through one participant's texts at a time and order relevant topics and episodes into a chronological, biographical account to create portraits that stay "true" to what participants narrate (Riessman 2008:74). In the crafting of each narrative portrait large, verbatim chunks of what participants narrated were used to stay true to their stories. The accounts of participants were not fractured in any way.

\section{Place the Participant at the Center of the Story Using Their Key Narratives, Storylines, or Plots}

The narrative should come together structurally around the key narratives, or storylines/plots, which underpin what the participant is telling the researcher, "documenting their voices and visionstheir authority, knowledge, and wisdom" (Golsteijn and Wright 2013:308). In each narrative portrait, Mishler's (1995) components for the analysis of narratives, with input from Johnstone (2016), provided structure for each story.

\section{Provide Rich Descriptions of the Experiences of Participants}

Rich descriptions that give meaning should be aimed for. Ensure a balance between the words of the participant and the interpretation that he or she provides (Bolivar 2002:13). A narrative portrait must display the participant's inner reality within the wider explainable context (Bolivar 2002:16). A well-written research portrait must be strongly specific and contextual and should portray "the richness, complexity, and dimensionality of human experience in social and cultural context" (Golsteijn and Wright 2013:300). Look for patterns in constructions of agency or positioning of participants (Shukla, Wilson, and Boddy 2014). Participants' self-positioning and their inner worlds that influenced their first-year experiences were brought to the fore. 


\section{Analysis and Findings}

The narrative analysis allowed a vertical analysis of each participant, facilitating the write-up of seven unique, authentic biographical narrative portraits. The presentation of these portraits answered the first research sub-question: "What are the first-year experience stories narrated by students in South African higher education?" The presentation of narrative portraits revealed seven unique first-year experience stories narrated by students in a South African private higher education institution and revealed their identities as first-year students. The narrative portraits told participants' stories of becoming first-year students from careful methodological vantage points to hear and their "voices," confirming the notion that unique, individual experiences are rich tapestries of personal experience and constitutive of identity formation.

The thematic analysis of narratives (Braun and Clarke 2006) allowed a horizontal analysis across the seven participants, resulting in five broad themes, most consisting of a variety of sub-themes, emerging across all seven participants. Common themes of the seven participants' experiences allowed theorization from the cases whilst keeping the individual stories intact. The presentation of the findings of the thematic analysis answered the second research question: "What are the common identity themes of first-year students based on their narratives of first-year higher education experience?" First, first-year student identities are formed by interpersonal experiences in their journeys. These experiences are characterized by their friendships, faith, family, and finances. Second, first-year student identities are formed by intrapersonal experiences in their journeys. These experiences are characterized by their personal experiences, their emotions, and their strengths and growth. Third, first-year student identities are formed by institutional experiences between leaving high school and before commencing study in their institutional journeys. Fourth, firstyear identities are formed by experiences of formal learning in their institutional journeys. These experiences were characterized by their experiences of formal learning characterized by the changes that they experienced between school and higher education and their academic experiences. Last, first-year identities are formed by learning experiences beyond the classroom. Their learning experiences were characterized by extra-curricular activities and their experiences of culture and cultural diversity at the institution.

\section{Discussion}

Due to the social turn being made in defining student identity in this study, it acknowledged that identity is socially constructed and constantly created and re-created in storied interactions by people and between people. Each participant told very different stories of their first-year experiences but there were common threads to their narratives. Although it must be acknowledged that the identities of people are self-evolving and fluid, the participants' myriad, complex paths that they traversed allowed a snapshot into their experiences. The stories were accepted for what they were at the time and used as a lens for an investigation into their identity development at the time of the study.

The narrative analysis revealed that their identity development resulted from situated interactions during their first year where they picked up institutional, intrapersonal, and interpersonal cues for learning their student identities. They developed their student identities through the everyday rituals 
(Sfard and Prusak 2005) of their new environment over their first year in higher education through personal and institutional experiences. In all cases, the participants' learning of whom they were expected to be as students was that they all somehow wanted to play according to "the rules of the game" (Boughey 2013) - they wanted to fit in and comply with what was expected of them. A close reading of the seven narrative portraits shows many instances of self-correcting and attempts to find their way as they navigated through the ritualized norms of their new institution. They all had an intense internal need to succeed in their first-year journeys. Congruent with the studies of Mahlangu and Fraser (2017) and McGhie (2017), the personal resilience, personal strengths, and efforts of the participants, and their ability to adapt to the expectations of their new institution, were vital tools that they used to adapt to and succeed in their first-year studies.

The study has various recommendations for practice: student-facing staff in marketing, admissions, and enrolment are often the first point of contact with prospective students. There is a need for these staff members to interact positively with students at all times with clear, ongoing communication to students as they navigate their way into institutions of higher learning.

The research process and findings indicate the need for higher education institutions to view the firstyear experience of students holistically to facilitate the positive identity development of students. Trusted representatives responsible in any way for first-year students have an impact on the types of identities developed by students. Their approach and interactions with first-year students should facilitate the sense that the institution is welcoming, supportive, and caring. The need for higher educa- tion institutions to intentionally create and foster a sense of belonging for all students is of paramount importance (Gyamera 2018:155).

This research shows that first-year students need "community" with peers. It is recommended that regular times are scheduled during first-year experience programs for students to come together to discuss their experiences and learn from others. These opportunities should allow students to share their experiences, often reflect with others, and learn from peers over the year to settle well into their new routines as students. Ideas for participation could include the various methods of field text collection (students interview each other, talk in small groups about their experiences, bring pictures or photographs that remind them of their year so far, draw their experiences, and reflect in small groups) used in this study.

There is a need for higher education institutions to plan vibrant, relevant, well-advertised first-year student experience programs encompassing the academic, cultural, personal, social, and sporting spheres to assist in building positive identities for new students.

Teaching and learning approaches should be adapted to integrate the socio-cultural context of the student and the disciplinary content and knowledge of what students are taught (Snowball and McKenna 2016). Academic staff should adapt their teaching and learning approaches, which harness the personal strengths and lived experiences of students. In doing this, the voices of culturally diverse students are also heard.

\section{Conclusion}

The study approached the narrative investigation with Kim's (2016:222) self-coined notion of "flirtation" by "capitalizing on imagination and creativ- 
ity to adapt, modify, and deepen existing analysis methods to address our narrative research design and process" to produce trustworthy and credible accounts of participants' first-year experiences. Allowing the participants an opportunity to select an already-taken image reminding them of their firstyear experience broadens the narrative methodological base in understanding commencing students' experiences in higher education by making use of images for research in a new and innovative way. Imagination, curiosity, and creativity were used to deepen existing analysis methods in the broader field of narrative research

As there is seldom a roadmap of how to conduct and analyze a narrative study, this research provides a living exemplar-a way in which such a complex research process could unfold. Researchers could use and adapt parts of the study as they see fit for future studies.

In employing a complementary methods design type using narrative and thematic methods for analysis, the study demonstrated the fluidity of the boundaries between the two approaches for analysis and facilitated deeper, richer understandings of students' transition experiences of the first year.

This study did not set out to exhaust how students experience their first year in higher education but rather to honor the voices of individual students to help facilitate better understandings of commencing students that higher education practitioners face every day.

The research implies the need for further research into how staff experiences their daily work with students in transition and how they can collaborate to ensure a smoother, meaningful transition experience for students, facilitating student identity devel- opment. Further, higher education institutions and practitioners may re-examine their practices, policies, procedures, and guidelines to better facilitate the "walk of the student" through the first year.

Research is encouraged to uncover how higher education institutions communicate their shared norms, values, and practices (Wolgemuth and Agosto 2019). The norms, values, and practices of higher education institutions are often discrete and hard to navigate for students who are new to higher education. Research into this area could facilitate a better "meeting" between first-year students and institutional expectations.

Given the COVID-19 pandemic, research is needed into how first-year students are developing firstyear student identities in an online learning context. There is a need for higher education institutions to innovate to keep first-year students engaged and develop the identities required for their academic and personal success in undergraduate study.

This study was based on research with a small number of student participants and, therefore, findings may not be transferable. The field text sets were collected in a unique, private higher education setting and may not have findings and recommendations beyond the periphery of the site at which the research was undertaken.

\section{Acknowledgments}

The study reported in this article was approved by the Ethics Committee of the Department of Education of the University of Johannesburg. We thank Professor Sarah Gravett (Professor and former Dean of the Faculty of Education at the University of Johannesburg) for her guidance in the study leading to this publication. 


\section{References}

Bagnoli, Anna. 2009. "Beyond the Standard Interview: The Use of Graphic Elicitation and Arts-Based Methods." Qualitative Research 9(5):547-570.

Banks, Marcus. 2001. Visual Methods in Social Research. London: Sage.

Berger, Roni. 2015. “Now I See It, Now I Don't: Researcher's Position and Reflexivity in Qualitative Research." Qualitative Research 15(2):219-234.

Bolivar, Antonio. 2002. “'¿De nobis ipsis silemus?': Epistemología de la investigación biográfico-narrativa en educación [De nobis ipse silemus?': Epistemology of Biographical Narrative Research in Education]." Revista Electrónica de Investigación Educativa 4(1). Retrieved December 03, 2021 (https://redie.uabc. $\mathrm{mx} /$ redie/issue/view/10).

Boughey, Chrissie. 2013. “What Are We Thinking of? A Critical Overview of Approaches to Developing Academic Literacy in South African Higher Education." Journal for Language Teaching 47(2):25-42.

Boughey, Chrissie and Sioux McKenna. 2016. "Academic Literacy and the Decontextualized Learner." Critical Studies in Teaching and Learning 4(2):1-9.

Braun, Virginia and Victoria Clarke. 2006. "Using Thematic Analysis in Psychology." Qualitative Research in Psychology 3:77-101.

Bruner, Jerome. 1986. Actual Minds, Possible Worlds. Cambridge, MA: Harvard University Press.

Bruner, Jerome. 1987. "Life as Narrative." Social Research 54(1):11-32.

Carolissen, Ronelle and Peace Kiguwa. 2018. "Narrative Explorations of the Micro-Politics of Students' Citizenship, Belonging and Alienation at South African Universities." South African Journal of Higher Education 32(3):1-11.

Chase, Susan E. 2011. "Narrative Inquiry." Pp. 421-434 in The Sage Handbook of Qualitative Research, edited by N. K. Denzin and Y. S. Lincoln. Thousand Oaks, CA: Sage.

Chinyamurundi, Willie. 2016a. “Using Narrative Analysis to Understand Factors Influencing Career Choice amongst a Sample of Distance Learning Students in South Africa." South African Journal of Psychology 46(3):390-400.
Chinyamurundi, Willie. 2016b. “A Narrative Investigation into the Meaning and Experience of Career Success: Perspectives from Women Participants." South African Journal of Human Resource Management 14(1):1-11.

Chinyamurundi, Willie. 2018. "Narratives of a Sense of Belonging: Perspectives from a Sample of International Students in South Africa." South African Journal of Higher Education 32(3):209-225.

Clandinin, Jean D. and Michael F. Connelly. 2000. Narrative Inquiry. Experience and Story in Qualitative Research. San Francisco: Jossey-Bass.

Coetzee, Jan K. and Asta Rau. 2017. "The Narrative Study of Lives: Editorial Notes." Qualitative Sociology Review 13(1):6-9.

Cohen, Louis, Lawrence Manion, and Keith Morrison. 2011. Planning Educational Research. Research Methods in Education. New York: Routledge.

Copeland, Andrea J. and Denise E. Agosto. 2012. “Diagrams and Relational Maps: The Use of Graphic Elicitation Techniques with Interviewing for Data Collection, Analysis, and Display." International Journal of Qualitative Methods 11(5):513-533.

Cresswell, John W. 2002. Educational Research: Planning, Conducting and Evaluating Quantitative and Qualitative Research. New Jersey: Merrill Prentice Hall.

Crilly, Nathan, John P. Clarkson, and Alan F. Blackwell. 2006. "Graphic Elicitation: Using Diagrams as Interview Stimuli." Qualitative Research 6(3):341-366.

Croghan, Rosaline et al. 2008. "Young People's Constructions of Self: Notes on the Use and Analysis of the Photo-Elicitation Methods." International Journal of Social Research Methodology 11(4):345-356.

Czarniawska, Barbara. 2004. Narratives in Social Science Research. London: Sage.

Denzin, Norman K. and Yvonna S. Lincoln. 2013. The Landscape of Qualitative Research. 4th ed. Thousand Oaks, London, New Delhi: Sage.

Eisner, Elliot. 2008. "Art and Knowledge." Pp. 3-12 in Handbook of the Arts in Qualitative Research: Perspectives, Methodologies, Ex- 
amples and Issues, edited by J. G. Knowles and A. L. Cole. Los Angeles, CA: Sage.

Emmison, Michael and Philip Smith. 2000. Researching the Visual: Images, Objects, Contexts, and Interactions in Social and Cultural Inquiry. London: Sage.

Evans, Jessica and Stuart Hall, eds. 1999. Visual Culture: The Reader. London: Sage and Open University.

Fisher, Catherine and Nancy White. 2001. "River of Life." Retrieved August 14, 2017 (http://www.kstoolkit.org/River+of+Life)

Fullana, Judit, Maria Pallisera, and Vila Montserrat. 2014. “Advancing Towards Inclusive Social Research: Visual Methods as Opportunities for People with Severe Mental Illness to Participate in Research." International Journal of Social Research Methodology 17(6):723-738.

Gauntlett, David and Peter Holzwarth. 2006. "Creative and Visual Methods for Exploring Identities.” Visual Studies 21(1):82-91.

Giamera, Gifty O. 2018. “I Just Want to Be Somebody: Exploring Students' Motivations and Experiences in Universities." South African Journal of Higher Education 32(3):154-171. doi: https://doi. org/10.20853/32-3-2544.

Giddens, Anthony. 1991. Modernity and Self-Identity. Self and Society in the Late Modern Age. Stanford, CA: Stanford University Press.

Gill, Scherto. 2005. “Learning across Cultures.” Ph.D. dissertation. Department of Education, University of Sussex, Brighton.

Gill, Scherto R. and Ivor F. Goodson. 2011. "Life History and Narrative Methods." Pp. 155-198 in Theory and Methods in Social Research, edited by B. Somekh and C. Lewin. London: Sage.

Golsteijn, Connie and Serena Wright. 2013. “Using Narrative Research and Portraiture to Inform Design Research." Pp. 298315 in IFIP Conference on Human-Computer Interaction, edited by P. Kotzé et al. Cape Town: Springer.

Guillemin, Marilys. 2004. “Understanding Illness: Using Drawings as a Research Method." Qualitative Health Research 14(2):272-289.

Guillemin, Marilys and Sarah Drew. 2010. "Questions of Process in Participant-Generated Visual Methodologies." Visual Studies 25(2):175-188.
Hardy, Barbara. 1968. "Towards a Poetics of Fiction: An Approach through Narrative." Novel 2(1):5-14.

Hitchcock, Graham and David Hughes. 1995. Research and the Teacher: A Qualitative Introduction to School-Based Research. 2nd ed. London: Routledge.

Hunter, Sally V. 2010. "Analyzing and Representing Narrative Data: The Long and Winding Road." Current Narratives 1(2):44-54.

James, Gwyneth. 2017. "Cul-de-sacs and Narrative Data Analysis-A Less than Straightforward Journey." The Qualitative Report 22(12):3102-3117.

Johnstone, Barbara. 2016. “'Oral Versions of Personal Experience': Labovian Narrative Analysis and Its Uptake." Journal of Sociolinguistics 20(4):542-560.

Josselson, Ruthellen, Amia Lieblich, and Dan McAdams, eds. 2003. Up Close and Personal: The Teaching and Learning of Narrative Research. The Narrative Study of Lives. American Psychological Association. doi: https://doi.org/10.1037/10486-000.

Kim, Jeong-Hee. 2016. Understanding Narrative Inquiry: The Crafting and Analysis of Stories as Research. Thousand Oaks, CA: Sage.

Labov, William and Joshua Waletzky. 1967. "Narrative Analysis. Essays on the Verbal and Visual Arts." Pp. 12-44 in Proceedings of the 1966 Annual Spring Meeting of the American ethnological Society, edited by J. Helm. Seattle: University of Washington Press.

Leitch, Ruth. 2008. “Creatively Researching Children's Narratives through Images and Drawings." Pp. 37-58 in Doing Visual Research with Children and Young People, edited by P. Thomson. Oxon: Routledge.

Mahlangu, Thoko and William J. Fraser. 2017. "The Academic Experiences of Grade 12 Top Achievers in Maintaining Excellence in First-Year University Programmes." South African Journal of Higher Education 31(1):104-118.

Maitlis, Sally. 2012. “Narrative Analysis.” Pp. 492-511 in Qualitative Organizational Research: Core Methods and Current Challenges, edited by G. Symon and C. Cassell. Thousand Oaks, CA: Sage.

Mason, Jennifer. 2006. "Mixing Methods in a Qualitatively Driven Way." Qualitative Research 6(9):9-25.

McAdams, Dan P. 1996. "Personality, Modernity, and the Storied Self: A Contemporary Framework for Studying Persons." Psychological Inquiry 7(4):295-321. 
McAdams, Dan K. and Kate C. McLean. 2013. "Narrative Identity." Current Directions in Psychological Science 22(3):233-238.

McCormack, Coralie. 2004. "Storying Stories. A Narrative Approach to Interview Conversations." International Journal of Social Research Methodology 7(3):219-236.

McDrury, Janice and Maxine Alteiro. 2003. Learning Through Storytelling in Higher Education. Sterling: Kogan Page.

McGhie, Venicia. 2017. “Entering University Studies: Identifying Enabling Factors for a Successful Transition from School to University." Higher Education 73:407-422.

McLellan, Hilary. 1994. "Situated Learning: Continuing the Conversation." Educational Technology 3(8):7-8.

Mirzoeff, Nicholas. 1999. An Introduction to Visual Culture. London: Routledge.

Mishler, Elliot G. 1986. Research Interviewing: Context and Narrative. Cambridge: Harvard University Press.

Mishler, Elliot G. 1995. “Models of Narrative Analysis: A Typology." Journal of Narrative and Life History 5(2):87-123.

Moussa, Ziad. 1994. "Rivers of Life.” New Mexico Department of Health, Public Health Division. Retrieved August 21, 2017 (https:// pubs.iied.org/pdfs/G02828.pdf).

Ngabaza, Sisa, Tamara Shefer, and Lindsay Clowes. 2018. "Students' Narratives on Gender and Sexuality in the Project of Social Justice and Belonging in Higher Education." South African Journal of Higher Education 32(3):139-153.

Pather, Subrethra and Rajendra Chetty. 2016. "Pre-Entry Factors Influencing First-Year Experience." South African Journal of Higher Education 30(1):1-21.

Patterson, Wendy. 2013. "Narratives of Events: Labovian Narrative Analysis and its Limitations." Pp. 27-46 in Doing Narrative Research, edited by M. Andrews, C. Squire, and M. Tamboukou. Thousand Oaks, CA: Sage.

Polkinghorne, Donald E. 1988. Narrative Knowing and the Human Sciences. Albany: State University of New York Press.

Ricouer, Paul. 1991. "Narrative Identity." Philosophy Today 35(1):73-81.

Riessman, Cathrine K. 2002. "Analysis of Personal Narratives." Pp. 695-710 in Handbook of Interview Research. Context and Meth- od, edited by J. F. Gubrium and J. A. Holstein. Thousand Oaks, London, New Delhi: Sage.

Riessman, Cathrine K. 2008. Narrative Methods for the Human Sciences. Thousand Oaks, CA: Sage.

Rodriguez, Sheri K. and Monica Reid Kerrigan. 2016. “Using Graphic Elicitation to Explore Community College Transfer Student Identity, Development, and Engagement." The Qualitative Report 21(6):1052-1070.

Rose, Gillian. 2001. Visual Methodologies. An Introduction to the Interpretation of Visual Materials. London: Sage.

Rose, Gillian. 2007. Visual Methodologies. An Introduction to the Interpretation of Visual Materials. 2nd ed. London: Sage.

Rose, Gillian. 2012. Visual Methodologies. An Introduction to the Interpretation of Visual Materials. 3rd ed. London: Sage.

Schiffrin, Deborah. 1996. “Narrative as Self-Portrait: Sociolinguistic Constructions of Identity." Language in Society 25(2):167-203.

Schulze, Salome. 2017. “The Value of Two Modes of Graphic Elicitation Interviews to Explore Factors That Impact on Student Learning in Higher Education." Qualitative Sociology Review 13(2):60-77.

Sfard, Anna and Anna Prusak. 2005. "In Search of an Analytic Tool for Investigating Learning as a Culturally Shaped Activity." Educational Researcher 34(4):14-22.

Shukla, Natasha, Emma Wilson, and Janet Boddy. 2014. “Combining Thematic and Narrative Analysis of Qualitative Interviews to Understand Children's Spatialities in Andhra Pradesh, India." Novella working paper: narrative research in action. National Centre for Research Methods: University of East London.

Singer, Jefferson. 2004. "Narrative Identity and Meaning-Making Across the Adult Lifespan: An Introduction." Journal of Personality 72(3):437-460.

Snowball, Jen and Sioux McKenna. 2016. “Student-Generated Content: An Approach to Harnessing the Power of Diversity in Higher Education." Teaching in Higher Education 22(5):604-618. doi: https://doi.org/10.1080/13562517.2016.1273205.

Somekh, Bridget and Cathy Lewin, eds. 2011. Theory and Methods in Social Research. London: Sage.

Sturken, Marita and Lisa Cartwright. 2001. Practices of Looking: An Introduction to Visual Culture. Oxford: Oxford University Press. 
Thornborrow, Joanna and Jennifer Coates. 2005. "The Sociolinguistics of Narrative: Identity, Performance, Culture." Pp. 1-16 in The Sociolinguistics of Narrative, edited by J. Thornborrow and J. Coates. Philadelphia: John Benjamins Publishing Company.

Van Leeuwen, Theo and Carey Jewitt, eds. 2001. The Handbook of Visual Analysis. London: Sage.
Wolgemuth, Jennifer R. and Vonzell Agosto. 2019. "Narrative Research." Pp. 1-3 in The Blackwell Encyclopedia of Sociology, edited by G. Ritzer and Ch. Rojek. John Wiley \& Sons. doi: https:// doi.org/10.1002/9781405165518.wbeos1244.

Yuval-Davis, Nira. 2006. "Belonging and the Politics of Belonging." Patterns of Prejudice 40(3):197-214.

\section{Citation}

Lees, Deborah and André Van Zyl. 2022. “Honoring Student 'Voice' in Investigating Student Identity Development in a Narrative Study: A Methodological and Analytical Example." Qualitative Sociology Review 18(1):28-49. Retrieved Month, Year (http:// www.qualitativesociologyreview.org/ENG/archive_eng.php). DOI: https://doi.org/10.18778/1733-8077.18.1.02 